\title{
The Association between Vitamin D Level and Chronic Pain and Depression in Premenopausal Women
}

\section{Premenopozal Erișkin Kadınlarda Vitamin D Düzeyi ile Kronik Ağrı ve Depresyon Arasındaki ilișki}

\author{
Halim YILMAZ1 ${ }^{1}$ Said BODUR², Gülten KARACA ${ }^{1}$ \\ 'Department of Physical Medicine and Rehabilitation, Konya Training and Research Hospital, Konya, Turkey \\ ${ }^{2}$ Department of Public Health, Balıkesir University Faculty of Medicine, Balıkesir, Turkey
}

\begin{abstract}
Objective: To investigate the association between vitamin $\mathrm{D}$ level and non-specific musculoskeletal system pain and depression in premenopausal women.

Material and Methods: Two hundred eighteen premenopausal women with common musculoskeletal pain and unknown etiology were included into the study. Levels of pain and depression were respectively measured with 0-10 visual analog scale (VAS) and Beck Depression Inventory (BDI). Levels of serum $25(\mathrm{OH}) \mathrm{D}$, parathormone, alkaline phosphatase, and calcium were also measured. The threshold value of vitamin $D$ was accepted as $20 \mathrm{ng} / \mathrm{mL}$. Patients with $25(\mathrm{OH}) \mathrm{D}<20 \mathrm{ng} / \mathrm{mL}$ were classified as the vitamin D deficiency group (group 1), and those with $\geq 20 \mathrm{ng} / \mathrm{mL}$ were accepted as the vitamin D group within normal limits (group 2).

Results: Of 218 participants, 174 (79.8\%) were detected with vitamin D deficiency, while 44 (20.2\%) were found with a normal level of vitamin D. A statistically significant difference was present between both groups as to VAS and BDI scores ( $p<0.001$ and $p=0.001$, respectively), although both groups were similar as to age, body mass index (BMI), level of income, duration of complaints, educational status, family type, and profession $(p>0.05)$. Whereas a negative correlation was present between level of vitamin D and VAS and BDI scores, no correlation was detected as to age, BMI, level of income, educational status $(p<0.001)$; duration of complaints, and number of children ( $p>0.05$ ).

Conclusion: Our study indicates that vitamin $D$ deficiency is a frequent finding in premenopausal women with chronic, non-specific musculoskeletal pain and that the level of vitamin $D$ is associated with levels of pain and depression.

Key Words: Vitamin D, pain, depression, women
\end{abstract}

Özet

Amaç: Premenopozal erişkin kadınlarda, D vitamini düzeyi ile nonspesifik kas- iskelet sistemi ağrısı ve depresyon arasındaki ilişkiyi araştırmak. Gereç ve Yöntemler: Çalışmaya, nedeni belirlenemeyen yaygın kasiskelet ağrısı bulunan 218 premenopozal kadın dahil edildi. Katılımcıların ağrı düzeyi 0-10 Vizüel Analog Skala (VAS) ile depresyon düzeyi ise Beck Depresyon Ölçeği (BDÖ) ile belirlendi. Katılımcıların serum 25(OH) $D$, parathormon, alkalen fosfataz ve kalsiyum düzeyleri belirlendi. $D$ vitamini sınır değeri $20 \mathrm{ng} / \mathrm{mL}$ olarak kabul edildi. $25(\mathrm{OH}) \mathrm{D}<20 \mathrm{ng} / \mathrm{mL}$ olan hastalar D vitamini eksikliği (Grup 1), $\geq 20 \mathrm{ng} / \mathrm{mL}$ olan hastalar ise D vitamini normal (Grup 2) olarak kabul edildi.

Bulgular: Iki yüz on sekiz katılımcının 174 'ünde $(\% 79,8)$ D vitamini eksikliği saptanırken, 44'ünde $(\% 20,2)$ D vitamininin normal sınırlarda olduğu tespit edildi. Gruplar yaş, beden kitle indeksi (BKI), gelir düzeyi, şikayet süresi, öğrenim durumu, aile tipi ve çalışma durumu yönünden benzer iken ( $p>0,05)$; VAS ve BDÖ skorları yönünden iki grup arasında istatistiksel olarak anlamlı fark mevcuttu ( $p<0,001$ ve $p=0,001$, sırasıyla) $D$ vitamini düzeyi ile VAS ve BDÖ skorları arasında negatif korelasyon saptanırken $(p<0,001)$; yaş, BKI, gelir düzeyi, öğrenim düzeyi, şikayet süresi ve çocuk sayısı arasında korelasyon tespit edilmedi $(p>0,05)$.

Sonuç: Çalışmamız kronik, nonspesifik kas-iskelet ağrısı olan premenopozal kadınlarda $D$ vitamini eksikliğinin sık bir bulgu olduğunu ve $D$ vitamini düzeyinin ağrı ve depresyon düzeyi ile ilişkili olduğunu göstermektedir.

Anahtar Kelimeler: D vitamini, ağrı, depresyon, kadın 


\section{Introduction}

One of the most significant symptoms decreasing the quality of life related to musculoskeletal disorders is pain. No underlying pathology is encountered in the majority of pains originating from disorders of the musculoskeletal system, and pains from the musculoskeletal system that are not based on a specific or underlying mechanical reason are called non-specific pains of the musculoskeletal system (1-4). Chronic non-specific musculoskeletal system pain and depression are serious public health problems, because the changes by chronic non-specific musculoskeletal system pain and depression affect not only the patient but also his/her family, employer, and related healthcare professionals. An interactive correlation is present between chronic pain and depression; chronic pain may lead to depression, or depressive patients may be encountered with the complaint of pain $(5,6)$. Vitamin $D$ is reported to have pro-apoptotic, anti-inflammatory, and immune-modulatory features and obtains calcium homeostasis. In addition to studies reporting the association between vitamin D deficiency and non-specific musculoskeletal system pain (7) and depression (8,9), there are also other studies reporting no association between non-specific musculoskeletal system pain $(10)$ and depression $(11,12)$. In our study, we aimed to investigate the association between vitamin $D$ level and non-specific musculoskeletal system pain and depression in premenopausal women.

\section{Material and Methods}

The study was performed in the outpatient clinic of the Physical Medicine and Rehabilitation Department of Konya Training and Research Hospital between September 2012 and April 2013. Two hundred eighteen premenopausal women who were admitted to the clinic due to non-specific musculoskeletal pains (e.g., low back, back, knee, shoulder, extremities, arthralgia, and common body pain) within the last 6 months and without underlying specific medical challenges (e.g., arthritis, trauma, depression, lumbar disc hernia, infection, neoplasm, metastasis, osteoporosis, rheumatoid arthritis, fracture, neurological disorders, and serious spinal pathology) were consecutively included into the study. Approval was obtained from the local ethical board of Meram Medical School of Necmettin Erbakan University. Those accepting to participate were informed, and their consents were obtained.

With common musculoskeletal system pain for at least 6 months, 218 premenopausal women were included into the study. Those with systemic disorders, major psychiatric diseases, history of antidepressant and anxiolytic drug intake, fibromyalgia, polymyalgia rheumatica, ankylosing spondylitis, rheumatoid arthritis, diffuse idiopathic skeletal hyperostosis, multiple myeloma, metastatic and metabolic bone diseases, a disorder or history of disorder affecting vitamin D metabolism (such as gastric surgery, chronic liver disease, renal failure, intestinal malabsorption), and the use of drugs affecting the levels of vitamin $\mathrm{D}$, parathormone, alkaline phosphatase, and calcium, cigarette smokers, those drinking alcohol regularly, within the menopausal cycle, and those with restricted mobility were excluded.
If necessary, laboratory and monitoring methods were used in order to have differential diagnostic criteria of chronic pain. Detailed history was obtained from each patient, and each participant was physically examined. Levels of pain severity and depression were respectively determined with the $0-10$ visual analog scale (VAS) and Beck Depression Inventory (BDI), and levels of parathormone, alkaline phosphatase, and calcium were measured. In order to determine vitamin D levels, 25(OH)D was investigated in blood samples drawn in the morning. 25-OH-D3 is the best clinical marker to show the condition of vitamin D, because it indicates total vitamin $D$ taken together with cutaneous synthesis and diet (13-15). The threshold value of vitamin $\mathrm{D}$ still remains controversial in the literature. For maximum calcium absorption and optimal health status, levels are suggested to be over $30 \mathrm{ng} / \mathrm{mL}$. However, $20 \mathrm{ng} / \mathrm{mL}$ is described as the threshold value of serum $25(\mathrm{OH}) \mathrm{D}$ preventing secondary hyperparathroidy, increased bone formation-resorption, and loss of bone mineral density (13).

In our study, the threshold value of serum 25(OH)D was accepted as $20 \mathrm{ng} / \mathrm{mL}$, and all participants were categorized as group 1 - the deficient group $(<20 \mathrm{ng} / \mathrm{mL})$, and group 2 - the normal group ( $\geq 20 \mathrm{ng} / \mathrm{mL}$ ). The Beck Depression Inventory (BDI), a valid and reliable method to measure depression level in society, is a 21-item survey evaluating items related to the symptoms of depression, such as hopelessness, irritability, cognitive problems, feelings of guilt or being punished, and physical symptoms, including fatigue, weight loss, and lack of sexual desire. A BDI score $\geq 17$ is consistent with the presence of depression (16). In our study, those with a BDI score of 17 and over were evaluated in favor of depression.

\section{Statistical Analysis}

All statistical analyses were performed using the IBM SPSS Release version 20. Appropriateness of variables to normal distribution rates was investigated with visual and analytical methods. Descriptive statistical data were presented as mean, standard deviation, numbers, and percentage. In the comparison of clinical features of participants with deficient and normal vitamin D levels, data appropriate for normal distribution rates were compared with student's t-test, and those inappropriate for normal distribution were compared with Mann Whitney Utest. In the comparison of frequencies, chi-square test was used. In order to define the linear association between independent variables and vitamin D level, Spearman's rho correlation coefficients were calculated. The statistical significance level was accepted as $\mathrm{p}<0.05$. As correlation coefficients, the correlations between 0-0.25 were assessed as "none," between 0.25-0.50 as "weak-moderate," between 0.50-0.75 as "severe," and between $0.75-1.00$ as "much severe."

\section{Results}

Of 214 participants, 174 (79.8\%) presented with vitamin D deficiency (group 1), while the level of vitamin D was within normal limits in 44 (20.2\%) (group 2). The socio-demographic and clinical data of all participants are presented in Table 1. While a statistically significant difference was observed in both groups 
as to VAS and BDI scores ( $p<0.001$ and $p=0.001$, respectively), no statistically significant difference was found as to age, body mass index (BMI), level of income, duration of complaints, educational status, family type, and profession ( $p>0.05$ ) (Table 1$)$. Depression level was $41.4 \%$ in group 1 , whereas the rate was $20.5 \%$ in group $2(p<0.001)$. In terms of levels of serum parathormone, alkaline phosphatase, and calcium, no significant difference was detected between groups 1 and 2 ( $p>0.05$ ) (Table 2). While a negative correlation was found between the groups as to vitamin D level and VAS and BDI scores $(r=-0.601, p<0.001$ and $r=-0.361, p<0.001$, respectively), no correlation was determined between the groups as to age, BMI, level of income, duration of complaints, and number of children $(p>0.05)$. However, a positive correlation was present between VAS and BDI scores $(p<0.001 r=-0.470)$.

\section{Discussion}

Vitamin D deficiency is a common problem both in Turkey and across the world. The most significant source of vitamin D is sunlight. Vitamin $D$ deficiency develops due to insufficient exposure to sunlight and poor absorption of vitamin $D$ via dieting, and the most marked finding is pain. The pain generally starts in the low back and may extend to the pelvis, hip, back, and costas $(17,18)$. It is reported that non-specific musculoskeletal pain due to vitamin $D$ deficiency originates from insufficient Ca-P and from the fact that poorly organized bone matrix presses outward onto the periost (19). Although non-specific musculoskeletal pain is one of the most common complaints of admissions to physical medicine and rehabilitation departments in daily practice, vitamin $\mathrm{D}$ deficiency is not considered frequently in the differential diagnosis, and high cost-effective diagnostic and therapeutic modalities are applied. In studies, however, it is reported that a low level of vitamin $D$ is a common symptom in those with non-specific and chronic musculoskeletal pain. Especially, the association between low level of vitamin $D$ and pain in osteomalacia is well established (20-24). Moreover, there are also studies reporting that a definite improvement is seen at the level of pain after vitamin D supplementation in patients with non-specific and chronic musculoskeletal system pain and vitamin D deficiency (25-27). As consistent with the literature, our study indicates that vitamin $D$ deficiency is a frequent finding in premenopausal women with non-specific musculoskeletal pain, and the level of pain is strongly associated with the level of vitamin D. Therefore, because its treatment is easy and pleasing when diagnosed, vitamin D deficiency as an underlying effect should be differentiated in musculoskeletal system pains with unknown etiology.

Depression is an important public health challenge due to its high prevalence and the loss of ability it causes (28). The prevalance of major depressive disorders was reported to be $21.3 \%$ in women (29). Lifelong prevalence of depression is higher in women, compared to men (30). It is emphasized that one of the reasons of depression leading to disorders in all fields of life is also vitamin $\mathrm{D}$ deficiency $(8,9,19,31-35)$. In a systematic review and meta-analysis performed recently in 31,424 individuals, an association was reported between depression and low levels of
Table 1. Socio-demographic and clinical data of patients

\begin{tabular}{|c|c|c|c|c|}
\hline & $\begin{array}{c}25(\mathrm{OH}) \mathrm{D}<20 \\
(\mathrm{n}=174)\end{array}$ & $\begin{array}{c}25(\mathrm{OH}) \mathrm{D} \geq 20 \\
(\mathrm{n}=44)\end{array}$ & & $\mathbf{p}$ \\
\hline Age (year) & $39.3 \pm 9.6$ & $42.1 \pm 8.8$ & & 0.092 \\
\hline $\mathrm{BMI}\left(\mathrm{kg} / \mathrm{m}^{2}\right)$ & $27.8 \pm 5.9$ & $26.6 \pm 4.7$ & & 0.205 \\
\hline $\begin{array}{l}\text { Level of income } \\
\text { (dollar/month) }\end{array}$ & $620.5 \pm 353.4$ & $678.0 \pm 420.8$ & & 0.187 \\
\hline Number of living children & $2.5 \pm 1.5$ & $2.2 \pm 1.0$ & & 0.109 \\
\hline $\begin{array}{l}\text { Duration of complaints } \\
\text { (month) }\end{array}$ & $18.5 \pm 17.5$ & $18.0 \pm 22.4$ & & 0.298 \\
\hline VAS scores & $7.6 \pm 1.8$ & $4.7 \pm 2.1$ & & $<0.001$ \\
\hline BDI scores & $14.9 \pm 8.9$ & $10.4 \pm 8.8$ & & 0.001 \\
\hline Marital status & n (\%) & n (\%) & $\chi^{2}$ & \\
\hline Married & $158(90.8 \%)$ & $42(95.5 \%)$ & 1.002 & 0.539 \\
\hline Single & 16 (\% 9.2\%) & $2(4.5 \%)$ & & \\
\hline \multicolumn{5}{|l|}{ Profession } \\
\hline Employed & $29(16.3 \%)$ & $9(20.9 \%)$ & 0.350 & 0.656 \\
\hline Unemployed & $145(83.7 \%)$ & $35(79.1 \%)$ & & \\
\hline \multicolumn{5}{|l|}{ Type of family } \\
\hline Core family & 107 (61.5\%) & 31 (70.5\%) & 1.214 & 0.298 \\
\hline Combined family & $67(38.5 \%)$ & $13(30.5 \%)$ & & \\
\hline Educational status & & & 0.884 & 0.829 \\
\hline Illiterate & $11(6.3 \%)$ & $3(6.8 \%)$ & & \\
\hline Primary (8 years) & $132(75.9 \%)$ & $29(72.7 \%)$ & & \\
\hline High school (11 years) & $15(8.6 \%)$ & $3(6.8 \%)$ & & \\
\hline College ( $\geq 12 y r s)$ & $16(9.2 \%)$ & $6(13.7 \%)$ & & \\
\hline
\end{tabular}

BMI: body mass index; BDI: beck depression inventory; VAS: visual analog scale

Table 2. Laboratory findings of patients

\begin{tabular}{lccc} 
& $\begin{array}{c}\mathbf{2 5}(\mathbf{O H}) \mathbf{D}<\mathbf{2 0} \\
(\mathbf{n}=\mathbf{1 7 4})\end{array}$ & $\begin{array}{c}\mathbf{2 5}(\mathbf{O H}) \mathbf{D} \geq \mathbf{2 0} \\
(\mathbf{n}=\mathbf{4 4})\end{array}$ & $\mathbf{p}$ \\
\hline 25-OH-D3 $(\mathrm{ng} / \mathrm{mL})$ & $9.3 \pm 3.4$ & $33.4 \pm 14.5$ & $<0.001$ \\
Parathormone & $63.9 \pm 28.7$ & $58.2 \pm 28.7$ & 0.351 \\
Alkaline phosphatase & $77.3 \pm 29.7$ & $75.5 \pm 28.3$ & 0.814 \\
Calcium & $9.3 \pm 0.4$ & $9.4 \pm 0.4$ & 0.073
\end{tabular}

vitamin $D(33)$. In a study where the patients with vitamin $D$ deficiency were included, Kaya et al. (27) treated the patients with vitamin $\mathrm{D}$ and calcium and reported that a significant alteration was observed in BDI scores 6 months after the followup. However, as well as studies reporting an association between depression and vitamin $\mathrm{D}$ deficiency, other studies reporting no correlation between depression and vitamin $\mathrm{D}$ deficiency are also present $(12,13,36-38)$. Upon evaluating $B D I \geq 17$ in favor of depression, the rates of depression were $41.4 \%$ in group 1 and $20.5 \%$ in group 2 in our study. In a previous study performed by Yilmaz et al. (39), the rate of depression was $8.3 \%$ in healthy women. The fact that the depression rate was also higher in group 2 within normal limits in our study is considered to arise 
from the fact that the patients with chronic non-specific musculoskeletal system pain constituted our study group and from the association between chronic pain and depression. It is reported that one of the disorders in which depression is commonly encountered is chronic pain syndrome, and at least $30 \%$ of such patients display major depression (6). Also, many neurons in the amygdala region of the brain and playing a key role in emotional status are reported to be associated with pain (40). In our study, vitamin $D$ deficiency and level of depression seem to be associated at a moderate level. However, considering the association between chronic pain and depression, we consider that more comprehensive studies are needed to suggest an association between vitamin $\mathrm{D}$ deficiency and depression.

Our study also has various limitations. First, because only women patients were included into the study, our findings can not be generalized to the whole population. Also, levels of depression in our participants were not evaluated via structured psychiatric interviews. So, further studies of both genders, including more participants to reflect a major part of the population, are needed.

\section{Conclusion}

As a result, our study indicates that vitamin D deficiency is a widespread finding in premenopausal women with chronic non-specific musculoskeletal pain and that vitamin D level is associated with level of pain and depression. Thus, vitamin D deficiency should be taken into account in premenopausal women, and the deficiency should be corrected, if any.

Ethics Committee Approval: Ethics committee approval was received for this study from the ethics committee of Necmettin Erbakan University Faculty of Medicine.

Informed Consent: Written informed consent was obtained from patients who participated in this study.

Peer-review: Externally peer-reviewed.

Author Contributions: Concept S.B., H.Y.; Design H.Y., S.B., G.K. Supervision - H.Y., S.B., G.K.; Funding - H.Y., S.B., G.K.; Data Collection and/or Processing - H.Y., S.B.; Analysis and/or Interpretation - H.Y., S.B.; Literature Review - H.Y.; Writer - H.Y.; Critical Review - H.Y., S.B., G.K.; Other - H.Y., S.B., G.K.

Acknowledgements: Authors would like to thank Numan Duran for language editing.

Conflict of Interest: No conflict of interests was declared by the authors.

Financial Disclosure: The authors declared that this study has received no financial support.

Etik Komite Onayı: Bu çalışma için etik komite onayı Necmettin Erbakan Üniversitesi Meram Tıp Fakültesi'nden alınmıştır.

Hasta Onamı: Yazılı hasta onamı bu çalışmaya katılan hastalardan alınmıştır.

\section{Hakem değerlendirmesi: Dış bağımsız.}

Yazar Katkıları: Fikir - S.B., H.Y.; Tasarım - H.Y., S.B., G.K.; Denetleme - H.Y., S.B., G.K.; Kaynaklar - H.Y., S.B., G.K.; Veri toplanması ve/veya işlemesi - H.Y., S.B.; Analiz ve/veya yorum - H.Y., S.B.; Literatür taraması - H.Y.; Yazıyı yazan - H.Y.; Eleştirel Inceleme - H.Y., S.B., G.K.; Diğer - H.Y., S.B., G.K.

Teşekkür: Yazarlar dil düzenlemesi için Numan Duran'a teşekkür eder.

Çıkar Çatışması: Yazarlar çıkar çatı̧̧ması bildirmemişlerdir.

Finansal Destek: Yazarlar bu çalışma için finansal destek almadıklarını beyan etmişlerdir.

\section{References}

1. Katz, N. The impact of pain management on quality of life. J Pain Symptom Manage 2002;24:38-47. [CrossRef]

2. Schreuder F, Bernsen RM, van der Wouden JC. Vitamin D supplementation for nonspecific musculoskeletal pain in non-Western immigrants: a randomized controlled trial. Ann Fam Med 2012;10:547-55. [CrossRef]

3. De Vries HJ, Reneman MF, Groothoff JW, Geertzen JH, Brouwer S. Self-reported work ability and work performance in workers with chronic nonspecific musculoskeletal pain. J Occup Rehabil 2013;23:1-10. [CrossRef]

4. Dıraçoğlu D. Musculoskeletal paın among medıcal staff. Turkiye Klinikleri J Med Sci 2006;26:132-9.

5. Durmuş D, Alaylı G, Cantürk F. Effects of biofeedback assisted ısometric exercise and electrical stimulation on pain, anxiety and depression scores in knee osteoarthritis. Turk J Phys Med Rehab 2005;51:142-5

6. Kara H, Abay E. Kronik ağrıya psikiyatrik yaklaşım. Anadolu Psikiyatri Dergisi 2000;1:89-99.

7. McBeth J, Pye SR, O’Neill TW, Macfarlane G], Tajar A, Bartfai G, et al. Musculoskeletal pain is associated with very low levels of vitamin $D$ in men: results from the European Male Ageing Study. Ann Rheum Dis 2010;69:1448-52. [CrossRef]

8. Jorde R, Sneve M, Figenschau Y, Svartberg J, Waterloo K. Effects of vitamin $D$ supplementation on symptoms of depression in overweight and obese subjects:randomized double blind trial. J Intern Med 2008;264:599-609. [CrossRef]

9. Hoang MT, Defina LF, Willis BL, Leonard DS, Weiner MF, Brown ES. Association between low serum 25-hydroxyvitamin $D$ and depression in a large sample of healthy adults: the Cooper Center longitudinal study. Mayo Clin Proc 2011;86:1050-5. [CrossRef]

10. Yener $M$. Kas iskelet sistem ağrısı ile vitamin $D$ düzeyleri arasındaki ilişkinin araştırılması. S.D.Ü. Tıp Fak. Derg 2007;14:7-11.

11. Pan A, Lu L, Franco OH, Yu Z, Li H, Lin X. Association between depressive symptoms and 25 -hydroxyvitamin $D$ in middle-aged and elderly Chinese. J Affect Disord 2009;118:240-3. [CrossRef]

12. Zhao G, Ford ES, Li C, Balluz LS. No associations between serum concentrations of 25-hydroxyvitamin $\mathrm{D}$ and parathyroid hormone and depression among US adults. Br J Nutr 2010;104:1696-702. [CrossRef]

13. Binkley N, Ramamurthy R, Krueger D. Low vitamin D status:definition, prevalence, consequences, and correction. Endocrinol Metab Clin North Am 2010;39:287-301. [CrossRef]

14. Calvo MS, Whiting SJ. Prevalence of vitamin D insufficiency in Canada and the United States: importance to health status and effi- 
cacy of current food fortification and dietary supplement use. Nutr Rev 2003;61:107-13. [CrossRef]

15. Alkan S, Sarsan A, Alkan H, Yıldız N, Topuz O, Ardıç F. Yaşlılarda vitamin $D$ düzeyleri ile denge, fiziksel performans ve yaşam kalitesi arasındaki ilişki. Turk J Geriatrics 2012;15:156-63.

16. Hisli N. Beck depresyon envanterinin geçerliliği üzerine bir çalışma. Psikoloji Dergisi 1988;22:118-26.

17. Heath KM, Elovic EP. Vitamin D deficiency: implications in the rehabilitation setting. Am J Phys Med Rehabil 2006;85:916-23. [CrossRef]

18. Parfitt AM. Osteomalacia and related disorders: Metabolic bone disease. Philadelphia: W.B. Saunders Co;1990.p.329-97.

19. Özkan B, Döneray H. D vitamininin iskelet sistemi dışı etkileri. Çocuk Sağlığı ve Hastalıkları Dergisi 2011;54:99-119.

20. Straube S, Andrew Moore R, Derry S, McQuay HJ. Vitamin D and chronic pain. Pain 2009;141:10-3. [CrossRef]

21. Plotnikoff GA, Quigley JM. Prevalence of severe hypovitaminosis D in patients with persistent, nonspecific musculoskeletal pain. Mayo Clin Proc 2003;78:1463-70. [CrossRef]

22. Mascarenhas R, Mobarhan S. Hypovitaminosis D-induced pain. Nutr Rev 2004;62:354-9. [CrossRef]

23. Benson J, Wilson A, Stocks N, Moulding N. Muscle pain as an indicator of vitamin $\mathrm{D}$ deficiency in an urban Australian Aboriginal population. Med J Aust 2006;185:76-7.

24. Atherton K, Berry DJ, Parsons T, Macfarlane G], Power C, Hyppönen E. Vitamin $D$ and chronic widespread pain in a white middle-aged British population: evidence from a cross-sectional population survey. Ann Rheum Dis 2009;68:817-22. [CrossRef]

25. De Torrente de Jara G, Pecoud A, Favrat B. Musculoskeletal pain in female asylium seekers and hypovitaminosis D3. BMJ 2004;329:1567. [CrossRef]

26. Al Faraj S, Al Mutairi K. Vitamin D deficiency and chronic low back pain in Saudi Arabia. Spine 2003;15:177-9. [CrossRef]

27. Kaya Ü, Saygı EK, Akyüz G. Yaşı kadınlarda D vitamini tedavisinin ağrı ve yaşam kalitesi üzerine etkileri. Osteoporoz Dünyasından 2010;16:9-12.

28. Whooley MA, Avins AL, Miranda J, Browner WS. Case-finding instruments for depression. J Gen Intern Med 1997;12:439-45. [CrossRef]
29. Noble RE. Depression in women. Metabolism 2005;54:49-52. [CrossRef]

30. Mete HE. Kronik hastalık ve depresyon. Klinik Psikiyatri 2008;11:3-18.

31. Ganji V, Milone C, Cody MM, McCarty F, Wang YT. Serum vitamin D concentrations are related to depression in young adult US population: the Third National Health and Nutrition Examination Survey. Int Arch Med 2010;3:29. [CrossRef]

32. Kjærgaard M, Joakimsen R, Jorde R. Low serum 25-hydroxyvitamin $D$ levels are associated with depression in an adult Norwegian population. Psychiatry Res 2011;30:221-5. [CrossRef]

33. Anglin RE, Samaan Z, Walter SD, McDonald SD. Vitamin D deficiency and depression in adults: systematic review and meta-analysis. Br J Psychiatry 2013;202:100-7. [CrossRef]

34. Jaddou HY, Batieha AM, Khader YS, Kanaan SH, El-Khateeb MS, Ajlouni KM. Depression is associated with low levels of 25-hydroxyvitamin D among Jordanian adults: results from a national population survey. Eur Arch Psychiatry Clin Neurosci 2012;262:321-7. [CrossRef]

35. Lee DM, Tajar A, O'Neill TW, O'Connor DB, Bartfai G, Boonen $S$, et al. Lower vitamin $D$ levels are associated with depression among community-dwelling European men. J Psychopharmacol 2011;25:1320-8. [CrossRef]

36. Kwasky AN, Groh CJ. Vitamin D and depression: is there a relationship in young women? J Am Psychiatr Nurses Assoc 2012;18:23643. [CrossRef]

37. Nanri A, Mizoue T, Matsushita Y, Poudel-Tandukar K, Sato M, Ohta $M$, et al. Association between serum 25-hydroxyvitamin $D$ and depressive symptoms in Japanese: analysis by survey season. Eur J Clin Nutr 2009;63:1444-7. [CrossRef]

38. Dumville JC, Miles JNV. Can vitamin D supplementation prevent winter-time blues? A randomised trial among older women. J Nutr Health Aging 2006;10:151-3.

39. Yilmaz H, Polat HA, Yilmaz SD, Erkin G, Kucuksen S, Salli A, et al. Evaluation of sexual dysfunction in women with rheumatoid arthritis: a controlled study. J Sex Med 2012;9:2664-70. [CrossRef]

40. Neugebauer V, Li W. Differential sensitization of amygdala neurons to afferent inputs in a model of arthritic pain. J Neurophysiol 2003;89:716-27. [CrossRef] 